\title{
Geographic Hematology: Some Observations in Mexico
}

\author{
Perla R. Colunga-Pedraza a Gisela B. Gomez-Cruz ${ }^{\text {b, c }}$ Julia E. Colunga-Pedraza ${ }^{a}$ \\ Guillermo J. Ruiz-Argüelles ${ }^{c-e}$ \\ a Universidad Autónoma de Nuevo León, Hospital Universitario, Monterrey, Mexico; ${ }^{b}$ Benemérita Universidad \\ Autónoma de Puebla, Puebla, Mexico; ${ }^{C}$ Centro de Haematología y Medicina Interna de Puebla, Clínica Ruiz, Puebla, \\ Mexico; ' Laboratorios Ruiz, Clínica Ruiz, Puebla, Mexico; eUniversidad Popular Autónoma del Estado de Puebla, \\ Puebla, Mexico
}

\section{Keywords}

Geographic hematology · Mexico · Overdiagnosis

\begin{abstract}
In 1963 Jean Bernard introduced the concept of "geographic hematology" and distinguished 2 branches, i.e., "ethnic hematology," which deals with differences between populations, and "environmental hematology," which considers factors such as food habits, infections, and others. Both of these branches have implications in the distribution of hematological diseases worldwide. In comparison with Caucasian populations, in Mexico a significantly higher prevalence of acute lymphoblastic, acute promyelocytic, and acute megakaryoblastic leukemias has been described. The rate of chronic myeloid leukemia seems to be as high as that reported in Caucasian populations, while other myeloproliferative neoplasias are significantly less frequent in Mexico. Significantly lower prevalences of hairy cell leukemia, chronic lymphocytic leukemia, multiple myeloma, and Waldenström's macroglobulinemia have been reported from Mexico. Regrettably, the influence of drug companies interested in selling their new and expensive drugs has resulted in both overdiagnosis of some diseases and overidentification of the refractory forms of some of these conditions to justify the use of unnecessary drugs.

(c) 2018 S. Karger AG, Basel
\end{abstract}

\section{Introduction}

Over the last years, population studies have reported remarkable differences in the incidence and characteristics of hematological diseases between geographic regions [1-4]. In 1963 Jean Bernard, an icon in the world of hematology, presented the concept of "geographic hematology" and distinguished 2 major branches, i.e., the so called "ethnic hematology," which deals with differences between populations, and "environmental hematology," which deals with environmental factors such as food habits, infections, and hematological diseases [5]. It has been shown that Mexico is not the exception and diverse studies have reported differences in rates of distinct hematological diseases when compared to other countries or regions. Non-Hispanic whites have been found to have higher incidence rates of acute myeloid leukemia (AML), chronic myeloid, and chronic lymphocytic leukemia (CLL) than Hispanics, while childhood acute lymphoblastic leukemia (ALL) incidence rates are highest among Hispanics [6]. Certain hematological malignancies have a different prevalence in our country compared to countries with a Caucasian population [7]. Our population has a significantly higher prevalence of M3 and M7 AML and a significantly lower prevalence of hairy cell leukemia, chronic lymphocytic leukemia, multiple myeloma (MM),

\section{KARGER}

(c) 2018 S. Karger AG, Basel

E-Mail karger@karger.com

www.karger.com/aha
Guillermo Ruiz-Argüelles, MD, FRCP (Glasg), MACP, DSc(hc)

Centro de Haematología y Medicina Interna de Puebla, Clínica Ruiz 8 B Sur 3710

Puebla 72530 (Mexico)

E-Mail gruiz1@ clinicaruiz.com 
and Waldenström's macroglobulinemia (WM) [8-14] (Fig. 1-3).

In this review we remark the salient features in the specific case of Mexico and its differences with other populations and describe the main differences for each disease compared to other geographic regions.

\section{Geographical Differences in Mexico}

\section{Acute Lymphoblastic Leukemia}

Although the etiology of ALL is unknown, numerous environmental factors, including radiation, chemicals products, and infections, have been associated with the disease. Descriptive epidemiologic studies have reported a higher incidence of ALL in the Latin American population compared to other racial/ethnic groups, leading to a search for possible factors that make the Mexican population more susceptible to developing the disease than others [15]. In Mexico, no large-scale epidemiologic studies have been conducted in this population, but some studies suggest the incidence of ALL in Mexico is among the highest in the world [16-19]. The worldwide incidence of ALL varies from 2.0 to 3.5 cases per 100,000 inhabitants per year, whereas in Mexico the incidence is higher than $6 / 100,000$ inhabitants per year $[18,20]$; the explanation for this difference is unknown. Mexican hematologists were the first to prove that malnutrition is an adverse prognostic factor in children with ALL [21], an observation that has been confirmed worldwide [22]. With regard to treatment of ALL, it has been shown that treatment protocols conducted on an outpatient basis are related to results similar to those of other more aggressive protocols endowed with a higher morbimortality but similar long-term results. As an example, we have shown that St. Jude's TOTAL XI-based protocols are as effective as Hyper-CVAD and, since they can be conducted on an outpatient basis, their use in Mexico is more realistic than that of other more complicated ones [23]. The mortality rate of Hyper-CVAD during its administration reaches more than $50 \%$ in some institutions, a figure substantially higher than that of the TOTAL XI-based schedules.

\section{Acute Myelogenous Leukemia}

In our low-to-middle income population the peak incidence of AML has been observed 10 years earlier than in other countries, with a mean age at diagnosis of 32-43 years $[15,24]$ compared to a median of 60-70 years in the USA or the UK $[25,26]$. As suggested by Jaime-Perez et al. [24], this might be explained by the fact that older pa-

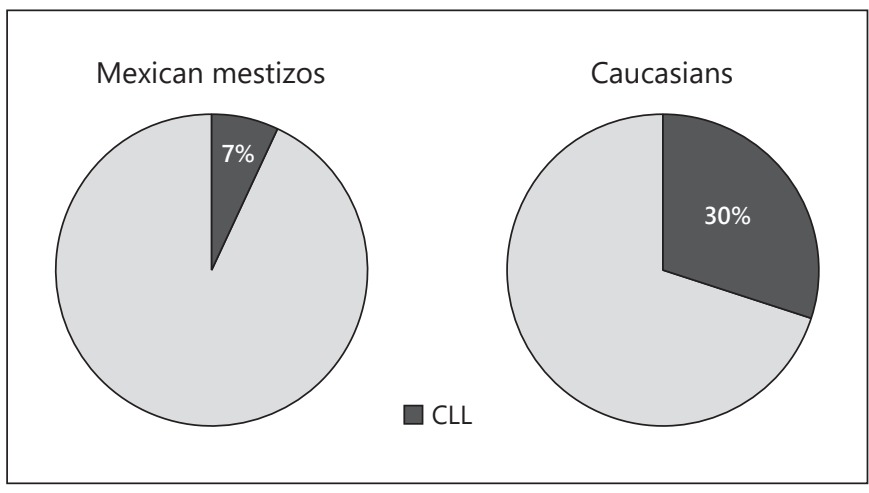

Fig. 1. Proportion of patients with chronic lymphocytic leukemia (CLL) within all the hematological malignancies in Mexican mestizos and Caucasians.

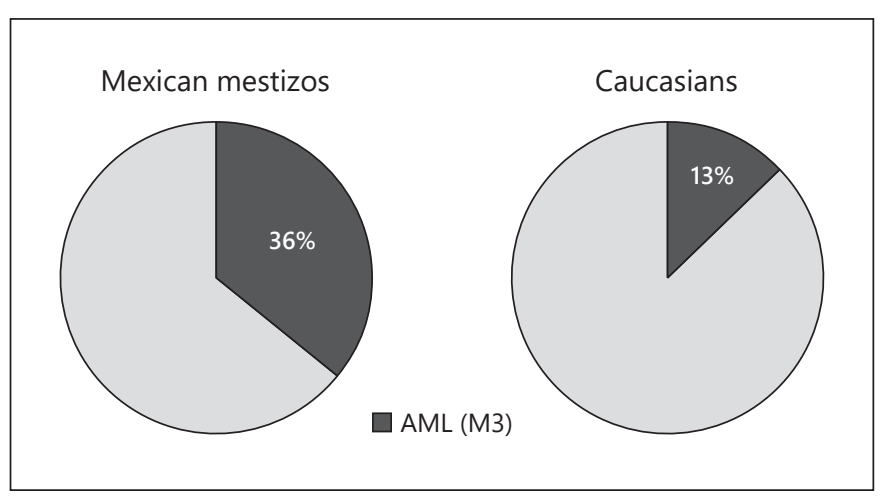

Fig. 2. Proportion of patients with acute promyelocytic leukemia (AML FAB M3) within all myeloblastic leukemias in Mexican mestizos and Caucasians.

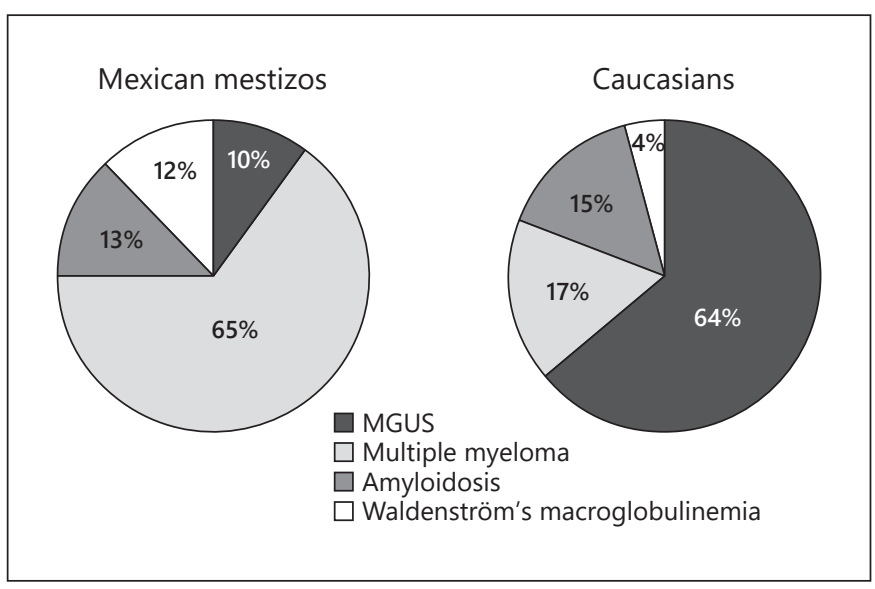

Fig. 3. Proportions of monoclonal gammopathies in Mexican mestizos and Caucasians. MGUS, monoclonal gammopathy of undetermined significance. 
tients are not referred to seeking care. The median age at diagnosis in Latin American countries or developing countries is very similar to ours. Brazil has reported a median age at diagnosis of 33-44 years $[27,28]$, and for other low-middle-income countries such as India and Malaysia the median age of patients with AML has been observed to be 40 and 39 years, respectively [29, 30]. The exact cause of this age difference is unclear. Socioeconomic factors including the aging population in developed countries and reduced access to healthcare in elderly patients in developing countries could explain these variations. Other factors such as environmental exposures and diet should be explored. Similar incidences of ALL and AML have been observed in Mexican adults, coinciding with other studies from Latin America and differing from reports from the USA, where AML is more common [15]. Interestingly, the median age of patients with AML is substantially lower in Mexicans than in Caucasians [15].

Particular attention is needed in the case of acute promyelocitic leukemia (APL) in Mexico. APL is the most common subtype of AML in Mexico, with an incidence of $35.5 \%[8,15]$, which is higher than the rate of around $5-13 \%$ reported in a Caucasian population [9] (Fig. 2). Latin Americans living in the USA have a greater frequency of APL compared to the the non-Latin American Caucasian population (i.e., 24.3 vs. $8.3 \%$ and age 31.5 vs. 46 years in Latin Americans vs. non-Latin Americans, respectively, as observed by Douer et al. [31]). This finding has also been observed in other Latin American countries such as Brazil (28.2\%) [32, 33], Venezuela (27.8\%) [34], and Peru (22\%) [35]. The geographic variation suggests a possible genetic predisposition or environmental exposures to specific risk factors. Other factors such as obesity and dietary patterns have been linked to APL $[36,37]$. An increased BMI has been independently associated with a higher incidence of APL in Latino patients living in the USA [37]. Seventy percent of the population of Mexico is overweight/obese, and this could partially explain the higher incidence of APL. The distribution of the breakpoint cluster regions of the PML/RARa fusion gene has been shown to be different in Mexican patients with APL than in Caucasians and similar to those observed in Asians [9]; this observation suggests genetic differences in the features of PML, with a higher predisposition for this disease in Mexico or, alternatively, a protective effect of these differences in Caucasians. As a result of the increased prevalence of APL in Latin America, multicenter studies employing a simplified treatment of the disease have been conducted, with results similar to those ob- tained in other populations employing more complicated treatment schedules [38]. It is also interesting that the prevalence of acute megakaryoblastic leukemia, the M7 variant of the FAB classification of AML, has also been described as more frequent in Mexicans than in Caucasians [39].

\section{Myeloproliferative Neoplasias}

There are data in Mexico indicating that the prevalence of chronic myelogenous leukemia is probably similar to that found in Caucasians [7]. However, we have found that MPN are considerably less frequent in Mexican mestizo populations than in Caucasian populations [35]. Essential thrombocythemia (ET) is the most frequent chronic myeloproliferative neoplasia (MPN) (i.e., 2.53 cases per 100,000 inhabitants per year) in the USA, followed by polycythemia vera [40]. In Mexico in a study of more than 8,000 individuals conducted between 1983 and 2001, chronic myelogenous leukemia was found to be as prevalent as in Caucausian populations, but ET, myelofibrosis, and polycythemia vera were significantly less frequent in Mexicans than in Caucasian populations [7]. It has been speculated that underdiagnosis of this particular group of diseases stemming from the unspecific and low symptoms presented in the burden of MPN may be related to the apparently diminished prevalence of these conditions. Despite the low prevalence of MPN in Mexico, drug companies have pushed the use of novel and expensive drugs such as ruxolitinib in patients in whom it is not clearly indicated.

\section{Chronic Lymphocytic Leukemia}

CLL is the most common leukemia in countries with a predominantly Caucasian population [41]; however, it is very rare in Asia and Latin America, including Mexico $[13,42,43]$. In Western countries CLL accounts for approximately $30 \%$ of all leukemias, in contrast to less than 7\% among Mexican mestizos [4] (Fig. 1). Some minor allele frequency differences have been observed in Mexican mestizos in contrast to the Caucasian population; however, the underlying causes for geographic variations have never been completely clarified [41]. In addition to these possible genetic differences, infectious, occupational, environmental, and genetic factors have all been suggested as other potential contributors [4]. It has also been shown that the clinical course of CLL in Mexico is less aggressive than the course in Caucasian populations [13]. This observation contrasts with the indiscriminate use of novel, expensive drugs in the treatment of refractory forms of CLL in Mexico as a result of pressure from drug 
companies to prescribe these novel drugs, which in turn has led to overdiagnosis of both the disease and the refractoriness of the condition; we have seen cases of persons with stage 0 CLL who need no treatment at all and who have been given treatment with ibrutinib or other novel and expensive drugs so that the physicians can be sponsored by drug companies to attend meetings, domestically and abroad. Hairy cell leukemia is infrequent in Mexico and, interestingly, it has been shown to have a geographic distribution [12], being more frequent in the northern states of the country, where inhabitants are more exposed to agricultural pesticides; this possible explanation is purely speculative.

\section{Malignant Monoclonal Gammopathies}

MM represents nearly $1 \%$ of all cancers and $15 \%$ of hematologic malignancies in the world $[44,45]$. However, its incidence varies among different regions and ethnic groups. The incidence of MM has been described as higher in blacks than in whites and lower in Asia than in Europe [46]. In general, there is a low prevalence of monoclonal gammopathy in Mexican mestizos compared to Caucasians [47]. In Mexico, the MM incidence represents $4.2 \%$ of hematologic malignancies, which is $2-3$ times less frequent than in Caucasians [48]. A diminished lower prevalence has also been reported in other monoclonal gammopathies in Mexico, like WM, representing 4.3\% of all the malignant monoclonal gammopathies and $0.18 \%$ of all hematological malignancies in Mexico, in contrast to $2 \%$ in the Caucasian population [14] (Fig. 3).

Monoclonal gammopathy of undetermined significance (MGUS) represents only $2.4 \%$ of all monoclonal gammopathies in Mexico, whereas in the Caucasian population MGUS affects about $3 \%$ of individuals aged $>70$ years; this figure is substantially lower in Mexico (i.e., $0.7 \%)$ [49]. A genetic basis for these geographic differences is suggested by similar low prevalences in other populations like the Japanese and the Chinese, which also have a low prevalence of MGUS [50]. Regarding systemic light chain amyloidosis, there is scarce information in Mexico. It has been found to be 14 times less prevalent in Mexican mestizos than in Caucasians. This difference could also be explained by underrecognition and low suspicion of the disease. In a multicenter study of the clinical features of MM in Latin America, it was shown that the clinical course of the disease is substantially less aggressive in inhabitants of Latin America than in Caucasians [51]; again this finding contrasts with the irrational use of novel antimyeloma drugs in Mexico, pushed by the drug companies, leading to indiscriminate use of novel, frequently unnecessary antimyeloma drugs. In our country, autologous stem cell transplant is still the best therapeutic approach for patients with MM and it has the best costbenefit ratio [52]. We strongly feel that it should be the main therapeutic option for these individuals.

\section{Thalassemia}

Thalassemia is considered the most common genetic disorder worldwide and approximately $3 \%$ of the world's population carries $\beta$-thalassemia genes [53]. Among the different ethnic populations and their geographical regions, there is a huge variation in the spectrum of $\beta$-globin gene mutations. In general, each population has its own $\beta$-globin gene mutation spectrum $[54,55]$. The disease is prevalent in the Mediterranean area, the Middle East, Africa, Southeast Asia, and the Indian subcontinent [55]. The precise prevalence of the carrier state of thalassemia in Mexico is not known but it appears to be not infrequent. Some $\beta$-thalassemia gene clusters have been found in the Mexican population, with a prevalence of up to $15 \%$ (in some areas these are autochthonous and in others they have been imported from the Mediterranean area) $[53,56]$. Information regarding $\alpha$-thalassemia in Mexico is scarce. $\boldsymbol{\alpha}$-thalassemia has been found to be responsible for $1 \%$ of hypochromic microcytic anemias in Mexico, which represents about half of the rate of $\beta$-thalassemia [57].

Non-Hodgkin's Lymphoma and Hodgkin's Lymphoma Substantial differences in the incidence of non-Hodgkin's lymphoma (NHL) across geographic regions have been reported. These seem to be related to host, racial, and environmental differences [58]. The highest NHL incidence rates are seen in developed countries in North America, Europe, and Oceania. NHL accounts for $4 \%$ of cancers in the USA [59]. However, there is data scarcity for less developed countries, and only few reports have addressed the epidemiology of NHL in Mexico and Latin America. One recent analysis of over 19,000 NHL cases revealed wide geographic variation in incidences and mortality rates in Central and South America. The highest incidence rates among males were observed in Uruguay, Colombia, Peru, and Ecuador (i.e., 10.2-10.9\%) and among females in Ecuador (i.e., 9.2\%) and Peru (i.e., $8.8 \%$ ), and these values were up to $40 \%$ lower than those observed in other countries (England, France, and Nor- 
way) and in North American countries for 2003-2007 [60]. A predominance of more aggressive subtypes of NHL has been described in Mexico and other developing countries $[61,62]$. Changes in exposure to risk factors, including infectious agents and immunosuppressive drugs, may be related to differences in demographic and geographic distribution patterns. Hodgkin lymphoma (HL) accounts for no more than $0.5 \%$ of the total cancer burden worldwide. There is a huge heterogeneity, with notable similarities and differences across patient populations regarding age, gender, and subtype [63]. In developing countries like Mexico, where HL seems to have a higher incidence, HL often presents at earlier ages and with a predominance of the mixed cellularity histologic subtype [64]. In developed countries the predominant histologic subtype is nodular sclerosis (70\% of cases); EBV-positive tumors are less frequently found, patients are diagnosed at earlier clinical stages (I-II), and there is a better prognosis for survival [65]. Concerning the therapeutic aspects of these diseases, in Mexico it has not been possible to prove a superiority of the employment of rituximab plus chemotherapy versus only chemotherapy in diffuse large B-cell lymphomas [66].

\section{Aplastic Anemia}

Aplastic anemia (AA) has been shown to be more frequent in Mexico than in Caucasian populations [67]. Interestingly, $50 \%$ of Mexican patients with AA in anemia have abnormalcies in the expression of CD55 and CD59, which suggests that they are hypoplastic variants of paroxysmal nocturnal hemoglobinuria [68]. Most Mexican patients with paroxysmal nocturnal hemoglobinuria have been found to have the hypoplastic variant of the disease [69]. Despite this finding, the indiscriminate use of eculizumab in Mexico has been the result of the efforts of the pharmaceutical industry, when it is known that only the hemolytic variants of the disease respond to this treatment. The most cost-effective treatment in Mexico for patients with AA is intensive immunosuppression [70], whereas bone marrow transplantation should be reserved for those AA patients not responding to immunosuppression [71].

\section{Discussion}

The concept of "geographic hematology" emerged in 1963 and opened a new chapter in hematology. This concept is very relevant and in the case of Mexico differences among the many hematological diseases are considerably significant when compared to other populations. These differences should be taken into account before taking for granted observations in other populations worldwide. Certain geographical variations in the frequency and clinical characteristics of hematological diseases have a different clinical profile and prevalence in Mexico compared to countries with Caucasian populations. The genetic mixture of Mexican mestizos is variable, but it comprises approximately 56\% American Indian genes, 40\% Caucasian genes, and $4 \%$ black genes [72].

In summary the population of Mexico has a significantly higher prevalence of M3 and M7 AML and an incidence of ALL among the highest in the world. There is a significantly lower prevalence of hairy cell leukemia, CLL, MM, and WM. Chronic myeloid leukemia seems to be as frequent as that reported in Caucasian populations, while other MPN are significantly less frequent in Mexicans. Considering the scarcity of well-designed registries and studies in Mexico, the geographical differences in Mexico may have resulted from artifacts in the data. However, there is enough information to affirm that environmental and genetic factors could be affecting. Socioeconomic factors including the aging population in developed countries and a reduced access to healthcare for elderly patients in developing countries could also explain some of the geographical variations. Other factors, such as infections, occupational exposure to chemicals, lifestyle factors, diet, and genetic susceptibility, should be explored to better understand the geographic differences in our country and thus establish potential preventive measures and therapeutics. Regrettably, the efforts of the pharmaceutical industry have resulted in changes in the landscape of many hematological diseases in Mexico by pushing the prescription and use of drugs that could be either avoided or replaced by other therapeutic approaches that are more realistic for individuals living in conditions with a restricted economy.

\section{Disclosure Statement}

The authors have no conflicts of interest to declare. 


\section{References}

1 Mousavi SM, Hemminki K: Cancer incidence, trends, and survival among immigrants to Sweden: a population-based study. Eur J Cancer Prev 2015;24(suppl 1):S1-S63.

2 Weiss NS: Geographical variation in the incidence of the leukaemias and lymphomas. Nat Cancer Inst Monogr 1979;139-142.

3 Lim JY, Bhatia S, Robison LL, Yang JJ: Genomics of racial and ethnic disparities in childhood acute lymphoblastic leukaemia. Cancer 2014;120:955-962.

4 Ruchlemer R, Polliack A: Geography, ethnicity and "roots" in chronic lymphocytic leukaemia. Leuk Lymphoma 2013;54:11421150 .

5 De Braekeleer M, De Braekeleer E, DouetGuilbert N: Geographic/ethnic variability of chromosomal and molecular abnormalities in leukaemia. Expert Rev Anticancer Ther 2015 15:1093-1102.

6 Matasar MJ, Ritchie EK, Consedine N, Magai C, Neugut AI: Incidence rates of the major leukaemia subtypes among US Hispanics, Blacks, and non-Hispanic Whites. Leuk Lymphoma 2006;47:2365-2370.

7 Ruiz-Argüelles GJ, Lopez-Martinez B, Lobato-Mendizabal E, Ruiz-Delgado GJ: An addition to geographic haematology: chronic myeloproliferative diseases are infrequent in Mexican Mestizos. Int J Haematol 2002;75 499-502.

8 Ruiz-Argüelles GJ: Promyelocytic leukaemia in Mexican mestizos. Blood 1997;89:348-349.

9 Ruiz-Argüelles GJ, Garces-Eisele J, ReyesNunez V, Gomez-Rangel JD, Ruiz-Delgado GJ: More on geographic haematology: the breakpoint cluster regions of the PML/RAR alpha fusion gene in Mexican mestizo patients with promyelocytic leukaemia are different from those in Caucasians. Leuk Lymphoma 2004;45:1365-1368.

10 Ruiz-Argüelles GJ, Lobato-Mendizabal E, San-Miguel JF, Gonzalez M, Caballero MD, Ruiz-Argüelles A, et al: Long-term treatment results for acute megakaryoblastic leukaemia patients: a multicentre study. Br J Haematol 1992;82:671-675.

11 Lobato-Mendizabal E, Ruiz-Argüelles GJ: Prevalence and features of pre-B-cell acute lymphoblastic leukaemia in Mexico: description of 9 patients. Sangre (Barc) 1991;36:1-5

12 Ruiz-Argüelles GJ, Cantu-Rodriquez OG Gomez-Almaguer D, Cortes-Franco J, Gongora-Biachi RA, Pizzuto J, et al: Hairy cell leukaemia is infrequent in Mexico and has a geographic distribution. Am J Haematol 1996;52: 316-318.

13 Ruiz-Argüelles GJ, Velazquez BM, AprezaMolina MG, Perez-Romano B, Ruiz-Reyes G, Ruiz-Argüelles A: Chronic lymphocytic leukaemia is infrequent in Mexican mestizos. Int J Haematol 1999;69:253-255.
14 Ruiz-Argüelles GJ, Ramirez-Cisneros FJ, Flores-Martinez J, Cernuda-Graham MC: Waldenstrom's macroglobulinemia is infrequent in Mexican mestizos: experience of a haematological diseases referral center. Rev Invest Clin 2000;52:497-499.

15 Gomez-Almaguer D, Marcos-Ramirez ER, Montano-Figueroa EH, Ruiz-Argüelles GJ, Best-Aguilera CR, Lopez-Sanchez MD, et al: Acute leukaemia characteristics are different around the world: the Mexican perspective. Clin Lymphoma Myeloma Leuk 2017;17:4651.

16 Perez-Saldivar ML, Fajardo-Gutierrez A, Bernaldez-Rios R, Martinez-Avalos A, MedinaSanson A, Espinosa-Hernandez L, et al: Childhood acute leukaemias are frequent in Mexico City: descriptive epidemiology. BMC Cancer 2011;11:355.

17 Mejia-Arangure JM, Bonilla M, Lorenzana R, Juarez-Ocana S, de Reyes G, Perez-Saldivar $\mathrm{ML}$, et al: Incidence of leukaemias in children from El Salvador and Mexico City between 1996 and 2000: population-based data. BMC Cancer 2005;5:33.

18 Fajardo-Gutierrez A, Juarez-Ocana S, Gonzalez-Miranda G, Palma-Padilla V, CarreonCruz R, Ortega-Alvarez MC, et al: Incidence of cancer in children residing in ten jurisdictions of the Mexican Republic: importance of the cancer registry (a population-based study). BMC Cancer 2007;7:68.

19 Bernaldez-Rios R, Ortega-Alvarez MC, Perez-Saldivar ML, Alatoma-Medina NE, Del Campo-Martinez Mde L, Rodriguez-Zepeda Mdel C, et al: The age incidence of childhood B-cell precursor acute lymphoblastic leukaemia in Mexico City. J Pediatr Haematol Oncol 2008;30:199-203.

20 Tlacuilo-Parra A, Garibaldi-Covarrubias R Romo-Rubio H, Soto-Sumuano L, RuizChavez CF, Suarez-Arredondo M, et al: Geographical distribution and cluster detection of childhood leukaemia in the metropolitan area of Guadalajara, Mexico. Rev Invest Clin 2017; 69:159-165

21 Lobato-Mendizábal E, Ruiz-Argüelles GJ, Marín-López A: Leukaemia and nutrition. 1. Malnutrition is an adverse prognostic factor in the outcome of treatment of patients with standard-risk acute lymphoblastic leukaemia. Leuk Res 1989;13:899-906.

22 Gómez-Almaguer D, Ruiz-Argüelles GJ, Ponce-de-León S: Nutritional status and socio-economic conditions as prognostic factors in the outcome of therapy in childhood acute lymphoblastic leukaemia. Int J Cancer Suppl 1998;11:52-55.

23 Ruiz-Delgado GJ, Macías-Gallardo J, LutzPresno JA, Montes-Montiel M, Ruiz-Argüelles GJ: Outcome of adults with acute lymphoblastic leukaemia treated with a pediatric-inspired therapy: a single institution experience. Leuk Lymphoma 2011;52:314316.
24 Jaime-Perez JC, Brito-Ramirez AS, PinzonUresti MA, Gutierrez-Aguirre H, Cantu-Rodriguez OG, Herrera-Garza JL, et al: Characteristics and clinical evolution of patients with acute myeloblastic leukaemia in northeast Mexico: an eight-year experience at a university hospital. Acta Haematol 2014;132:144151

25 Dores GM, Devesa SS, Curtis RE, Linet MS, Morton LM: Acute leukaemia incidence and patient survival among children and adults in the United States, 2001-2007. Blood 2012 119:34-43.

26 Forman D, Stockton D, Moller H, Quinn M, Babb P, De Angelis R, et al: Cancer prevalence in the UK: results from the EUROPREVAL study. Ann Oncol 2003;14:648-654.

27 Padilha SL, Souza EJ, Matos MC, Domino NR: Acute myeloid leukaemia: survival analysis of patients at a university hospital of $\mathrm{Pa}$ rana. Rev Bras Haematol Hemoter 2015;37: 21-27.

28 Pulcheri W, Spector N, Nucci M, de Morais JC, Pimenta G, de Oliveira HP: The treatment of acute myeloid leukaemia in Brazil: progress and obstacles. Haematologica 1995;80:130 135 .

29 Meng CY, Noor PJ, Ismail A, Ahid MF, Zakaria Z: Cytogenetic profile of de novo acute myeloid leukaemia patients in Malaysia. Int J Biomed Sci 2013;9:26-32.

30 Bahl A, Sharma A, Raina V, Kumar L, Bakhshi S, Gupta R, et al: Long-term outcomes for patients with acute myeloid leukaemia: a singlecenter experience from AIIMS, India. Asia Pac J Clin Oncol 2015;11:242-252.

31 Douer D, Preston-Martin S, Chang E, Nichols PW, Watkins KJ, Levine AM: High frequency of acute promyelocytic leukaemia among Latinos with acute myeloid leukaemia. Blood 1996;87:308-313.

32 Rego EM, Jacomo RH: Epidemiology and treatment of acute promyelocytic leukaemia in latin america. Mediterr J Haematol Infect Dis 2011;3:e2011049.

33 Melo RA, de Vasconcellos JF, Melo FC, Machado CG, Lacerda TM, Souto FR: PMLRARalpha fusion gene transcripts and biological features in acute promyelocytic leukaemia patients. Clin Lab Haematol 2006;28. 126-129.

34 De Salvo L, Weir Medina J, Gomez Sanchez O, de Baena ES, de Ramos BU, Guevara J, et al: Acute promyelocytic leukaemia in the west of Venezuela (in Spanish). Sangre (Barc) 1989;34:329-331.

35 Otero JC, Santillana S, Fereyros G: High frequency of acute promyelocytic leukaemia among Latinos with acute myeloid leukaemia. Blood 1996;88:377.

36 Li S, Chen L, Jin W, Ma X, Ma Y, Dong F, et al: Influence of body mass index on incidence and prognosis of acute myeloid leukaemia and acute promyelocytic leukaemia: a metaanalysis. Sci Rep 2017;7:17998. 
37 Estey E, Thall P, Kantarjian H, Pierce S, Kornblau S, Keating M: Association between increased body mass index and a diagnosis of acute promyelocytic leukaemia in patients with acute myeloid leukaemia. Leukaemia 1997;11:1661-1664.

38 Rego EM, Kim HT, Ruiz-Argüelles GJ, Undurraga MS, Uriarte MeR, Jacomo RH, et al: Improving acute promyelocytic leukaemia (APL) outcome in developing countries through networking, results of the International Consortium on APL. Blood 2013;121: 1935-1943.

39 Ruiz-Argüelles GJ, Marín-Lopez A, LobatoMendizábal E, Ruiz-Argüelles A, Nichols WL, Katzman JA: Acute megakaryoblastic leukaemia: a prospective study of its identification and treatment. Br J Haematol 1986;62:55-63.

40 Mesa RA, Silverstein MN, Jacobsen SJ, Wollan PC, Tefferi A: Population-based incidence and survival figures in essential thrombocythemia and agnogenic myeloid metaplasia: an Olmsted County Study, 1976-1995. Am J Haematol 1999;61:10-15.

41 Hernandez-Caballero A, Arellano-Llamas AA, Cruz-Rico J, Ojeda JV, Tuna-Aguilar E, Aguayo-Gonzalez A, et al: Genetic susceptibility variants for chronic lymphocytic leukaemia in Mexican mestizos. Br J Haematol 2015;169:909-911.

42 Boggs DR, Chen SC, Zhang ZN, Zhang A: Chronic lymphocytic leukaemia in China. Am J Haematol 1987;25:349-354.

43 Dores GM, Anderson WF, Curtis RE, Landgren $\mathrm{O}$, Ostroumova $\mathrm{E}$, Bluhm EC, et al: Chronic lymphocytic leukaemia and small lymphocytic lymphoma: overview of the descriptive epidemiology. Br J Haematol 2007; 139:809-819.

44 Hungria VT, Maiolino A, Martinez G, Duarte GO, Bittencourt R, Peters L, et al: Observational study of multiple myeloma in Latin America. Ann Haematol 2017;96:65-72.

45 Alexander DD, Mink PJ, Adami HO, Cole P, Mandel JS, Oken MM, et al: Multiple myeloma: a review of the epidemiologic literature. Int J Cancer 2007;120(suppl 12):40-61.

46 Benjamin M, Reddy S, Brawley OW: Myelo$\mathrm{ma}$ and race: a review of the literature. Cancer Metastasis Rev 2003;22:87-93.

47 Hernandez-Reyes J, Galo-Hooker E, RuizDelgado GJ, Ruiz-Argüelles GJ: Systemic immunoglobulin light-chain amyloidosis (AL) in México: a single institution, 30-year experience. Rev Invest Clin 2012;64(6 Pt 2):604608.

48 Ruiz-Argüelles GJ, Gomez-Rangel JD, RuizDelgado GJ, Aguilar-Romero L: Multiple myeloma in México: a 20-year experience at a single institution. Arch Med Res 2004;35: 163-167.
49 Ruiz-Delgado GJ, Gomez Rangel JD: Gamopatía monoclonal de significado indeterminado en mestizos mexicanos: experiencia de una sola institución. Gac Meed Meex 2004;140:375-379.

50 Ruiz-Delgado GJ, Ruiz-Argüelles GJ: Genetic predisposition for monoclonal gammopathy of undetermined significance. Mayo Clin Proc 2008;83:601-602; author reply 2-3.

51 Hungria VTM, Lee JH, Maiolino A, De Queiroz Crusoe E, Martinez G, Bittencourt R, et al: Combined analysis of 3,664 patients with multiple myeloma (MM) from Latin America (LA) and Asia. Blood 2017;130(suppl 1):5386.

52 López-Otero A, Ruiz-Delgado GJ, Ruiz-Argüelles GJ: A simplified method for stem cell autografting in multiple myeloma: a single institution experience. Bone Marrow Transplant 2009;44:715-719.

53 Ruiz-Argüelles GJ, Lopez-Martinez B, RuizReyes G: Heterozygous beta-thalassemia: not infrequent in Mexico. Arch Med Res 2001;32: 293-295.

54 De Sanctis V, Kattamis C, Canatan D, Soliman AT, Elsedfy H, Karimi M, et al: Beta-thalassemia distribution in the Old World: an ancient disease seen from a historical standpoint. Mediterr J Haematol Infect Dis 2017; 9:e2017018.

55 Murad H, Moasses F, Dabboul A, Mukhalalaty Y, Bakoor AO, Al-Achkar W, et al: Geographical distribution of beta-globin gene mutations in Syria. Haematology 2018;1-8.

56 Reyes Cruz G, Hernandez Acasiete M, Ruiz Reyes G: Identification of a focus of beta-thalassemia in Tamiahua, Veracruz (in Spanish). Rev Invest Clin 1990;42:189-192.

57 Reyes-Nunez V, Garces-Eisele J, Jorge S, Kimura E, Ferreira-Costa F, Sonati Mde F, et al: Molecular characterization of alpha-thalassemia in the Mexican population. Rev Invest Clin 2006;58:234-236.

58 Anderson JR, Armitage JO, Weisenburger DD: Epidemiology of the non-Hodgkin's lymphomas: distributions of the major subtypes differ by geographic locations. NonHodgkin's Lymphoma Classification Project. Ann Oncol 1998;9:717-720.

59 Muller AM, Ihorst G, Mertelsmann R, Engelhardt M: Epidemiology of non-Hodgkin's lymphoma (NHL): trends, geographic distribution, and etiology. Ann Haematol 2005;84: $1-12$.

60 Diumenjo MC, Abriata G, Forman D, Sierra MS: The burden of non-Hodgkin lymphoma in Central and South America. Cancer Epidemiol 2016;44(suppl 1):S168-S177.

61 Jaime-Perez JC, Gamboa-Alonso CM, Vazquez-Mellado-de-Larracoechea A, Rodriguez-Martinez $\mathrm{M}$, Gutierrez-Aguirre $\mathrm{CH}$, Marfil-Rivera LJ, et al: Non-Hodgkin lymphomas: impact of rituximab on overall survival of patients with diffuse large B-cell and follicular lymphoma. Arch Med Res 2015;46: 454-461.
62 Jemal A, Siegel R, Xu J, Ward E: Cancer statistics, 2010. CA Cancer J Clin 2010;60:277300 .

63 Kusminsky G, Abriata G, Forman D, Sierra MS: Hodgkin lymphoma burden in Central and South America. Cancer Epidemiol 2016; 44(suppl 1):S158-S167.

64 Rendon-Macias ME, Valencia-Ramon EA, Fajardo-Gutierrez A, Castro-Rios A: Incidence of childhood Hodgkin's lymphoma in Mexico by histologic subtypes and socioeconomic regions. J Pediatr Haematol Oncol 2016;38:e97-e101.

65 Punnett A, Tsang RW, Hodgson DC: Hodgkin's lymphoma across the age spectrum: epidemiology, therapy, and late effects. Semin Radiat Oncol 2010;20:30-44.

66 Ruiz-Delgado GJ, Gómez-Almaguer D, Tarín-Arzaga LC, Cantú-Rodriguez OG, Urdaneta CA, Rodríguez-Morales $\mathrm{U}$, et al: Is there a benefit to adding rituximab to $\mathrm{CHOP}$ in the overall survival of patients with B-cell non-Hodgkin's lymphoma in a developing country? Haematology 2012;17:193-197.

67 Ruiz-Argüelles GJ, Katzmann JA, Greipp PR, Marín-López A, González-Llaven J, CanoCastellanos R: Lymphocyte subsets in patients with aplastic anaemia. Am J Haematol 1984; 16:267-275.

68 Ruiz-Argüelles GJ, Ramírez Cisneros FJ, Ruiz-Argüelles A, Pérez-Romano B, MoralesAceves R: Glycosilphosphatidylinositol-anchored cell surface protein deficiency in Mexican mestizo patients with aplastic anaemia (in Spanish). Rev Invest Clin 1999;51:5-9.

69 Hernández-Reyes J, González-Ramírez MP, Martagón-Herrera N, Rosales-Durón AD, Ruiz-Delgado GJ, Ruiz-Argüelles GJ: Paroxysmal nocturnal hemoglobinuria in México: a 30-year, single institution experience. Rev Invest Clin 2014;66:12-16

70 Delgado-Lamas JL, López-Karpovitch X, Marín-López A, Romero-García F, Ruiz-Argüelles GJ, Ruiz-Gonzalez DS, et al: Low doses of high-potency antithymocyte globulin (ATG) in severe aplastic anaemia: experience with the Mexican ATG. Acta Haematol 1989; 81:70-74

71 Gómez-Almaguer D, Vázquez-Mellado A, Navarro-Cabrera JR, Abello-Polo V, Milovic V, García J, et al: The Latin American experience of allografting patients with severe aplastic anaemia: real-world data on the impact of stem cell source and ATG administration in HLA-identical sibling transplants. Bone Marrow Transplant 2017;52:41-46.

72 Lisker R, Ramirez E, Briceño RP, Granados J, Babinsky V: Gene frequencies and admixture estimates in four Mexican urban centers. Hum Biol 1990;62:791-801. 